\title{
Addition of water-soluble soy extract and probiotic culture, viscosity, water retention capacity and syneresis characteristics of goat milk yogurt
}

\author{
Adição de extrato hidrossolúvel de soja e cultura probiótica e características de viscosidade, capacidade \\ de retenção de água e de sinerese de iogurte produzido com leite de cabra
}

\author{
Danielle Cristina Guimarães da Silva ${ }^{I^{*}}$ Luiz Ronaldo de Abreu ${ }^{\mathrm{I}}$ Giovana Maria Pereira Assumpção
}

\begin{abstract}
Yogurts from goat milk were elaborated and watersoluble soybean extract (WSSE) and Bifidobacterium lactis probiotic culture added during processing. The characteristics of apparent viscosity, water retention capacity and syneresis were analyzed during 29 days of storage and it was verified the influence of WSSE and the probiotic on these rheological properties. The suplementation of WSSE provoked an increase in the viscosity and water retention capacity of the yogurts while reducing the syneresis. The inoculation of the probiotic culture during elaboration of the yogurts did not significantly alter the rheological characteristics of the products. Therefore, the water-soluble soybean extract and the probiotic culture can contribute to the rheological characteristics of yogurts, besides the nutritional and functional improvement advantages already known with the use of these products.
\end{abstract}

Key words: yogurt, water-soluble soy extract, rheology.

\section{RESUMO}

Iogurtes a base de leite de cabra foram elaborados e a eles adicionados extrato hidrossolúvel de soja (EHS) e de cultura probiótica Bifidobacterium lactis durante o processamento. As características de viscosidade aparente, capacidade de retenção de água e sinerese foram analisadas durante 29 dias de armazenamento e verificadas a influência do EHS e do probiótico nestas propriedades reológicas. A suplementação de EHS provocou aumento na viscosidade e capacidade de retenção de água dos iogurtes e, ao mesmo tempo, a sinerese foi reduzida. A inoculação da cultura probiótica durante elaboração dos iogurtes não alterou de forma significativa as características reológicas dos produtos. Portanto, a adição de extrato hidrossolúvel de soja e a cultura probiótica, pode contribuir para melhora nas características reológicas de iogurtes, além das vantagens na melhoria nutricional e funcional já conhecidas com a utilização destes produtos.

Palavras-chave: iogurte, extrato hidrossolúvel de soja, reologia.

\section{INTRODUCTION}

TAMINE \& DEETH (1980), define yogurt as being the product resulting from the fermentation of milk, which is possible by the initial culture obtained from a combination of Streptococcus thermophilus and Lactobacillus delbuechii subsp. Bulgariccus, being the use of other microbial cultures allowed. The world production and consumption of yogurts grew considerably during the last century, a fact attributed to the increased use of probiotics organisms by the food industries.

Goat milk has been described as a highly digestible product with important allergenic properties when compared to cow's milk. It presents advantages such as smaller fat globules (FRAZIER, 1995), goat milk also has high calcium and A and B complex vitamin levels (ALFÉREZ et al., 2006). In spite of the countless benefits of goat milk, currently a high rejection of this product is verified, resulting in its low consumption. For OLIVEIRA (2009) among the viable alternatives to stimulate the consumption of this type of milk is its use

IDepartamento de Ciência dos Alimentos, Universidade Federal de Lavras (UFLA), CP 3037, 37200-000, Lavras, MG, Brasil. Email: daniellenut@hotmail.com.*Autor para correspondência.

IIInstituto Federal de Ciência, Educação e Tecnologia (Sudeste de Minas Gerais ), Campus Barbacena, Barbacena, MG, Brasil. 
in the elaboration of milk drinks, yogurts and cheeses. The elaboration of the mentioned products based on goat milk, such as yogurt, can present significant alterations in its rheological properties, such as low consistency and a tendency towards whey separation (syneresis). Therefore, to obtain satisfactory results with fermented goat milk products, the addition of stabilizers is recommended. According to LORENZEN et al. (2002), the enrichment of the dry matter content and/or the proteic content are standard measures used to avoid syneresis and to improve the texture of the yogurt. As such, the soy proteins, specifically, the water-soluble soybean extract (WSSE), deserves prominence to improve the nutritional value of the product and to affect the gel structure formation of the yogurt.

The combination of a product supplemented with proteins and fermented by probiotic microorganisms can generate a product with technological and functional properties that meet demands for healthy products. In that context, this research aimed to evaluate the influence of WSSE and the probiotic culture in the viscosity profile and syneresis of yogurts, during its shelf life.

\section{MATERIAL AND METHODS}

\section{Characterization of raw material}

The milk used in the experiment was originated from a goat herd, through milking of females of the Saanen race, under appropriate hygienic conditions. The physiochemical analyses were carried out with milk samples in triplicata, to proof its quality. Consisted of the determination of the $\mathrm{pH}$ by direct potentiometry in a digital pHmeter (ADOLFO LUTZ, 1985), titratable acidity, density, fat and total soluble solids percentage (BRAZIL, 2006).

\section{Elaboration of the yogurt}

The methodology used in this study for the development of the yogurt, was based on that described by TAMINE \& ROBINSON (1991). The yogurts were prepared and identified with letters according to their processing particularities (addition of WSSE adjusted to the proteic level of the milk at the concentration of $20 \%$, resulting in the suplementation of $14.8 \mathrm{~g} \mathrm{~L}^{-1}$ of WSSE and $2 \%$ Bifidobacterium lactis probiotic culture), as expressed under.

- Yogurt A: without addition of WSSE, without addition of probiotic culture.

- Yogurt B: adding WSSE (20\%), without addition of probiotic culture.

- Yogurt C: without addition WSSE, with addition of probiotic culture.
-Yogurt D: adding WSSE (20\%), with addition of probiotic culture.

The rheological analyses of the products were conducted on the $1 \mathrm{st}, 15^{\text {th }}$ and $29^{\text {th }}$ day postproduction.

\section{Apparent viscosity of yogurt}

Samples of yogurt were homogenized, and then about $500 \mathrm{~mL}$ were poured into a becker to conduct the analysis. The apparent viscosity was determined in programmable digital viscosimeter 1 (Brookfield, model DV-II+), using cylindrical $\mathrm{n}^{\mathrm{0}} 2$ and 3 probes, and a speed of 50rpm (PELEGRINE et al., 2000). The results were expressed in Centipoise (cP).

Water retention capacity (expressible moisture) of yogurt

It was evaluated by expressible moisture (EM) according to the methodology proposed by JAUREGUI et al. (1981), with modifications by BEUSCHEL et al. (1992). Samples of the yogurts $(1 \mathrm{~g} \pm 0.15)$ were weighed on Whatman filter paper number 2 and centrifuged at 700xg (2500rpm in a centrifuge) for 10 minutes at $6^{\circ} \mathrm{C}$. The percentage of expressible moisture humidity was calculated through the difference in weight between the dry and wet filter paper. Each sample was analyzed twice

\section{Syneresis of yogurt}

Samples of 30 grams of yogurt were distributed evenly on filter paper (Whatman 1,Sigma) on top of a funnel connected to a $50 \mathrm{ml}$ graduated cylinder. After 5 hours of drainage at $4^{\circ} \mathrm{C}$, the syneresis index was calculated (RIENER et al., 2010), through the equation: [(weight of the whey after filtration/weight of the yogurt sample) $x$ 100]

\section{Statistical analysis}

The treatments were evaluated through variance analysis (ANOVA), followed by the ScottKnott Test, to 5\% of significance, using the R statistical program (R DEVELOPMENTE CORE TEAM, 2009) software.

\section{RESULTS AND DISCUSSION}

\section{Characterization of raw material}

The results of the physiochemical analysis of the goat milk used in the yogurt treatments are 6,68 from $\mathrm{pH}, 0.17 \mathrm{~g}$ lactic acid $100 \mathrm{~mL}^{-1}$ of product from titratable acidity, 1,02 $\mathrm{g} \mathrm{L}^{-1}$ from density, 3,1\% from fat 
and $11,5 \%$ from total soluble solids. These results were similar to those found by LORA et al. (2006). The results found for $\mathrm{pH}$ were similar to the values obtained by research done in the state of São Paulo by GOMES et al. (2004). The average value found for the goat milk acidity was $0,17 \mathrm{~g}$ lactic acid $100 \mathrm{~mL}^{-1}$ of product. Such an average is within the standards required by the legislation (BRAZIL, 2000).

The average fat value obtained in the raw milk by the Gerber method was above the minimum (3\%) required by the legislation for whole milk. Density of the goat milk was within the norms of the current legislation (BRAZIL, 2000). RICHARDS et al. (2001) evaluated the pasteurized whole goat's milk, average total solid values from 12,08 to $12,23 \%$.

\section{Rheological properties of viscosity}

The rheological property of apparent viscosity of a product significantly influences the acceptance and consumer purchase intention, thus being an important factor that should be controlled during the yogurt processing. It was observed that the apparent viscosity of the yogurts underwent an increase during storage, and can be seen in figure 1 .

There was an increase in the viscosity of the yogurts during storage. This fact is due to the fermentation process of the lactic acid bacteria (LAB) used in milk products that synthesize short chain fatty acids, vitamins and exopolysaccharides (EPS) (SHENE \& BRAVO, 2006). The exopolysaccharides have an important function as a natural bio-thickening agent to improve the rheology of the fermented product, as physical stabilizer and to retain water and limit the syneresis (DUBOC \& BEAT, 2001).

The treatments supplemented with WSSE codified with the letters B and D presented higher viscosity by the increase of total solids, provoked by the dry matter addition, that also aids in the gel formation. According to MANGINO (1984), with the increase of the proteic concentration, modification of the gel texture occurs, resulting in increased firmness and intensifying the water retention by the matrix.The desnaturation of the $\beta$-lactoglobulin and its interaction with the casein micelles had a great influence on the properties of gel formation in fermented milks (MARTÍNDIANA et al., 2003). The lactic acid bacteria (LAB) had an important function as natural bio-thickening agent to improve the reology of the fermented product, as physical stabilizer and to retain water and limit the syneresis (DUBOC \& BEAT, 2001). According to RICCIARDI \& CLEMENTI (2000) bifidobacteria are capable of producing EPS in large amounts. The varied rheological behavior in fermented milks can be attributed to the differences in the multiplication speed of the bacteril culture (GASSEM \& FRANK, 2001).

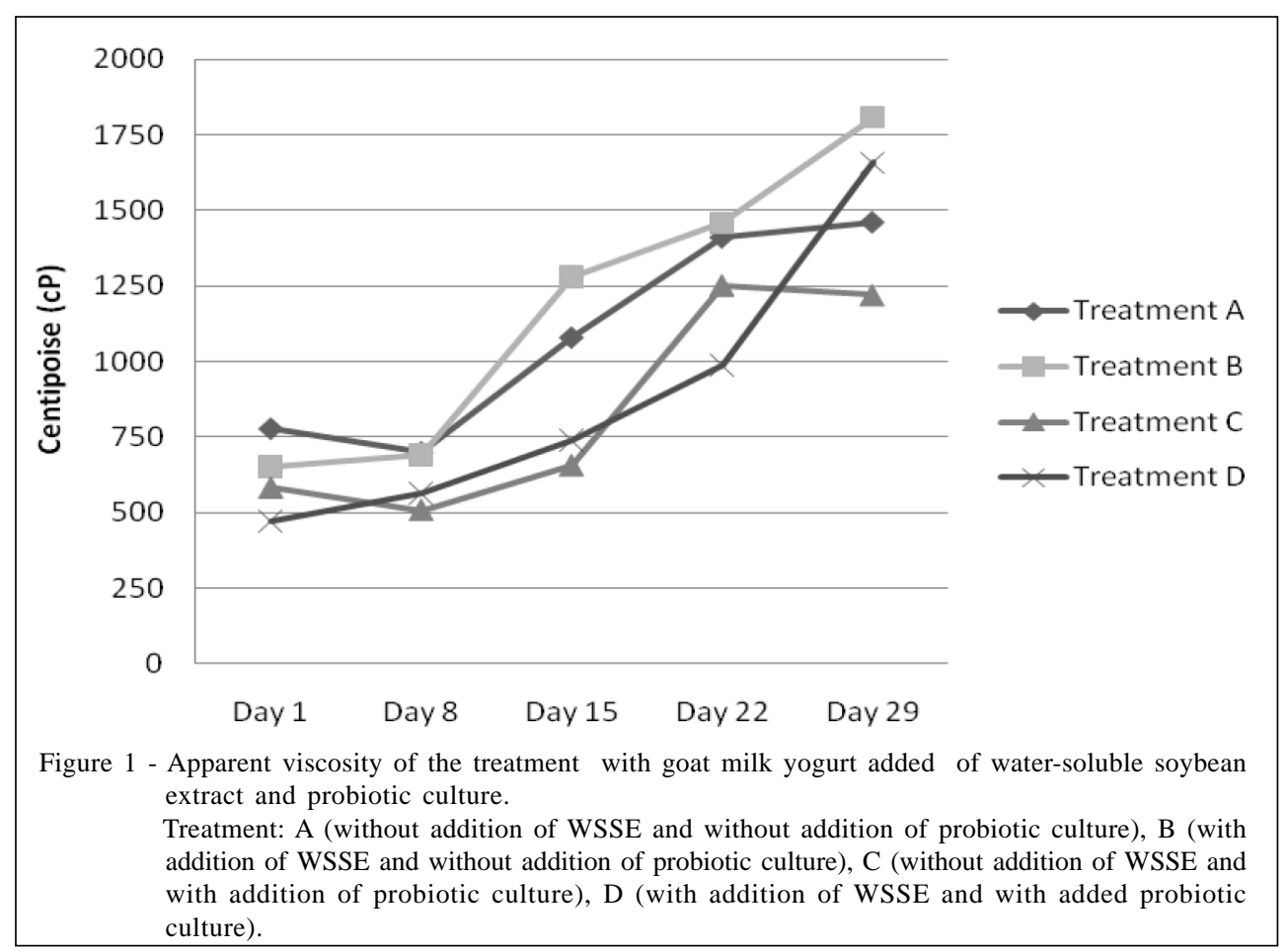

Ciência Rural, v.42, n.3, mar, 2012. 
Water retention capacity

The physical properties of the yogurt, including the separation of the whey (syneresis), play an important role in the product quality and consumer acceptance. Therefore, to increase the water retention capacity of yogurt production is suggested the inhibition of syneresis. The common reasons for the occurrence of this alteration include the use of a high incubation temperature, high whey protein concentrations in relation to the casein, low total solid concentration and physical alteration of the product during storage and distribution (LUCEY, 2004). The results of the analysis of water retention capacity of yogurts based on goat's milk are presented in table 1 .

The analyzed treatments presented high water retention capacity values, however they underwent a decrease during storage. Different rheological behavior with lower values was found by MORETI (2009) when evaluating yogurts with different concentrations of proteic supplement.

The water retention capacity on the $1 \mathrm{st}, 15^{\text {th }}$ and $29^{\text {th }}$ day post-production of the yogurts showed that there was no significant difference among the treatments $(\mathrm{P} \leq 5)$.

The treatments codified with the letters A and $\mathrm{B}$ presented a decrease in the water retention capacity during storage. According to JAROS \& ROHM (2003), susceptibility to syneresis tends to decrease with the increase of the yogurt solid matter. This suggests that the supplementation with soy extract can be used with success in the production of yogurts, because it stabilizes the separation of the whey.

Table 1 - Mean values (\%) of water holding capacity of samples of fermented milk made with goat milk (A), goat milk added with water-soluble soybean extract (WSSE) (B), goat milk with added probiotic culture (C) and goat milk added WSSE and probiotic culture (D).

\begin{tabular}{lccc}
\hline \multirow{2}{*}{ Fermented Milk } & \multicolumn{3}{c}{------Water retention capacity (\%)------- } \\
& Day 1 & Day 15 & Day 29 \\
\hline A & $86,90 \mathrm{a}$ & $85,00 \mathrm{a}$ & $77,45 \mathrm{a}$ \\
B & $90,10 \mathrm{a}$ & $85,00 \mathrm{a}$ & $82,00 \mathrm{a}$ \\
C & $80,45 \mathrm{a}$ & $77,50 \mathrm{a}$ & $73,20 \mathrm{a}$ \\
D & $88,00 \mathrm{a}$ & $84,50 \mathrm{a}$ & $79,20 \mathrm{a}$ \\
CV (\%) & 2,84 & 8,63 & 8,02 \\
\hline
\end{tabular}

Means followed by same letter don't differ statistically among themselves, by Test Average Scott-Knott, to 5\% probability.
In the treatments $\mathrm{C}$ and $\mathrm{D}$, the analyzed water retention was slightly inferior to the other treatments, however, the yogurt supplemented with WSSE, identified by the letter $\mathrm{D}$, presented less syneresis that product $\mathrm{C}$, without supplementation. Therefore it was observed that with addition of Bifidobacterium lactis, the water retention capacity in the treatments was reduced. Similar results were verified by SAXELIN et al. (1999) in milk fermented by probiotic strains.

Syneresis of yogurts

The syneresis reduction of the whey corresponds to the improvement of the water retention capacity of proteins, which increases with denaturation (BRITTEN \& GIROUX, 2001; MARTIN DIANA et al., 2003). The average syneresis values can be seen in figure 2 .

It is observed that there was a tendency towards an increase in the syneresis values in all of the appraised yogurts during the storage time. However, it is worth pointing out that in the treatments with added soy extract, the susceptibility to syneresis was lower. In the treatments where there was inoculation of the probiotic bacterium Bifidobacterium lactis, the syneresis values accompanied the treatments in which there was no soy extract addition and, as such, little influence of this procedure is noticed.

LIMA (2001) when evaluating the syneresis in yogurts with added whey protein concentrate (WPC) verified that the increase in the protein fortification tends to reduce the syneresis. MARTIN-DIANA et al. (2003) when developing fermented milk based on cow's and goat's milk containing probiotic culture and soy protein verified a higher syneresis tendency of the fermented milk elaborated with goat's milk and reduction of the susceptibility to syneresis with the increase in the amount of protein. This fact suggests that the soy can be used to elaborate fermented milk products by acting on the control of whey separation.

\section{CONCLUSION}

This study showed that the addition of water-soluble soybean extract in the yogurts elaborated from goat's milk propitiated better viscosity and water retention capacity characteristic. The use of probiotic culture showed little influence on these rheological properties. The syneresis of the yogurts was lower in the treatments with added soy extract, the addition of probiotic culture provoked a reduction in this characteristic.

Ciência Rural, v.42, n.3, mar, 2012. 


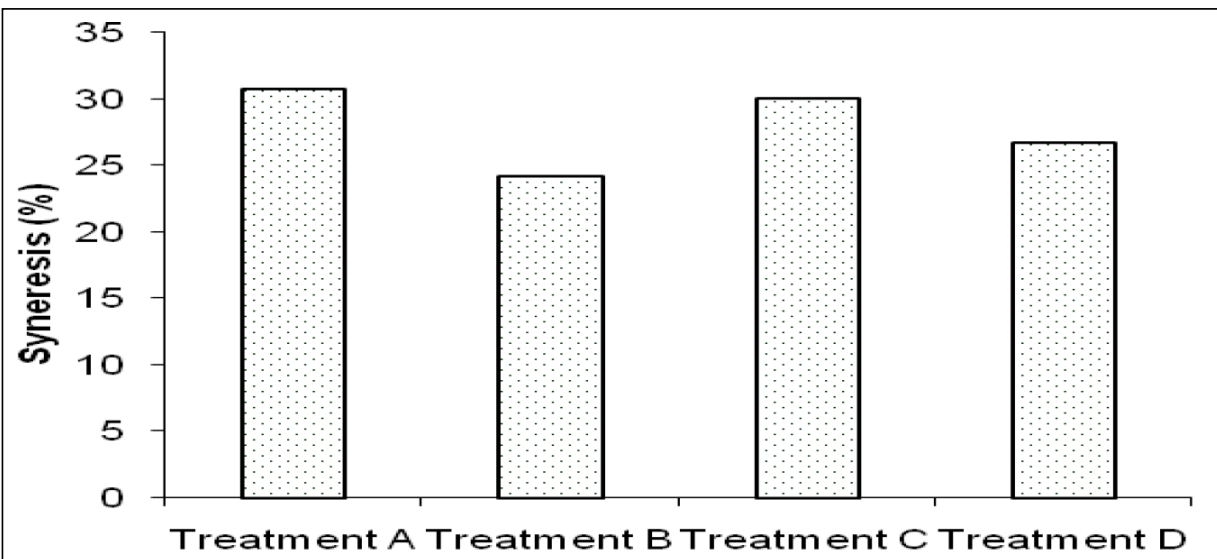

Figure 2 - Mean values of syneresis treatment with goat milk yogurt added of water-soluble soybean extract and probiotic culture.

Treatment: A (without addition of WSSE and without addition of probiotic culture), B (with addition of WSSE and without addition of probiotic culture), C (without addition of WSSE and with addition of probiotic culture), D (with addition of WSSE and with addition of probiotic culture).

\section{REFERENCES}

ALFÉREZ, M.J.M. et al. Dietary goat milk improves iron bioavailatability in rats with induced ferropenic anaemia in comparison with cow milk. International Dairy Journal, v.16, p.813-821, 2006. Available from: <http:// w w w. sciencedirect.com/science/article/pi i / S0958694605001615>. Accessed: Fev. 17, 2011. doi: 10.1016 j.idairyj.2005.08.001

BEUSCHEL, B.C. et al. Gelation and emulsification propertires of partially insolubilized whey protein concentrates. Journal of Food Science, v.57, n.3, p.605-609, 1992. Available from: <http://onlinelibrary.wiley.com/doi/10.1111/j.13652621.1992.tb08053.x/abstract>. Accessed: Nov. 28, 2010. doi: 10.1111/j.1365-2621.1992.tb08053.x.

BRASIL, Ministério da Agricultura, Pecuária e Abastecimento. Instrução Normativa n. 37 de 08 de novembro de 2000 Regulamento técnico de identidade e qualidade do leite de cabra. Diário Oficial da União, Brasília, 09 nov. 2000. Available from:: <http://extranet.agricultura.gov.br/sislegis-consulta/ consultarLegislacao.do?operacao=visualizar\&id=18164> . Accessed: Dez. 15, 2010.

BRASIL. Ministério da Agricultura, Pecuária e Abastecimento. Métodos analíticos oficiais físico-químicos para controle de leite e produtos lácteos. Instrução Normativa n. 68, de 12 de dezembro de 2006.

BRITTEN, M.; GIROUX, H.J. Acid-induced gelation of whey protein polymers: Effects of $\mathrm{pH}$ and calcium concentration during polymerization. Food Hydrocolloids, v.15, p.609617, 2001. Available from: <http://www.sciencedirect.com/ science/article/pii/S0268005X01000492>. Accessed: Dez. 5, 2010. doi: 10.1016/S0268-005X(01)00049-2.

DUBOC, P.; BEAT, M. Aplications of exopolysaccharides in the dairy industry. International Dairy Journal, v.11, n.10, p.759-
768, 2001. Available from: <http://www.sciencedirect.com/ science/article/pii/S0958694601001194>. Accessed: Jan. 20 2011. doi: 10.1016/S0958-6946(01)00119-4.

FRAZIER, C.A. Food allergies got your goat? A “nanny” may help wean grown-ups from milk. Total Health, v.17, p.46-47, 1995.

GASSEM, M.A.; FRANK, J.F. Physical properties of yogurt made from milk treated with proteolitic enzymes. Journal of Dairy Science, v.74, p.1503-1511, 1991. Available from: <http://www.sciencedirect.com/science/article/pii/ S0022030291783100>. Accessed: Fev. 15, 2011. doi: 10.3168/ jds.S0022-0302(91)78310-0.

GOMES, V. et al. Influência do estágio de lactação na composição do leite de cabras (Capra hircus). Brazilian Journal of Veterinary Research and Animal Science, v.41, n.5, p.339-342, 2004. Available from: <http:// www.scielo.br/scielo.php?script=sci_arttext\&pid=S141395962004000500008\&lng=en\&nrm=iso>. Accessed: Jan. 28, 2011. doi: 10.1590/S1413-95962004000500008.

INSTITUTO ADOLFO LUTZ. Normas analíticas do Instituto Adolfo Lutz. 3.ed. São Paulo: IMESP, 1985. V.1, 533p.

JAROS, D.; ROHM, H. Controlling the texture of fermented dairy products: the case of yoghurt. In: SMIT, G. (Ed.). Dairy processing: improving quality. Cambridge: Woodhead Publishing; Boca Raton: CRC, 2003. Chap.8.

JAUREGUI, C.A. et al. A simple centrifugal method for measuring expressible moisture, a water-binding property of muscle foods. Journal of Food Science, v.46, p.1271-1273, 1981.

LIMA, S.C.G. Efeito da adição de concentrado protéico de soro e leite em pó desnatado na fabricação de iogurte 
firme. 2001. 87f. Dissertação (Mestrado em Tecnologia de Alimentos) - Curso de Pós-graduação em Tecnologia de Alimentos, Universidade Estadual de Campinas, SP.

LORA, S.C.P. et al. Avaliação sensorial de sorvetes elaborados com leite de cabra. Semina: Ciências agrárias, v.27, n. 2, p.221-230, 2006.

LORENZEN, P.C. et al. Effect of enzymatic cross-linking of milk proteins on functional properties of set-style yoghurt. International Journal of Dairy Tecnology, v.55, n.3, p.152157, 2002. Available from: <http://onlinelibrary.wiley.com/ doi/10.1046/j.1471-0307.2002.00065.x/full>. Accessed: Dez. 15, 2010. doi: 10.1046/j.1471-0307.2002.00065.x.

LUCEY, J.A. Cultured dairy products: an overview of their gelation and texture properties. International Journal of Dairy Technology, v.57, n.2-3, p.77-84, 2004. Available from: <http://onlinelibrary.wiley.com/doi/10.1111/j.14710307.2004.00142.x/abstract>. Accessed: Fev. 21, 2011. doi: 10.1111/j.1471-0307.2004.00142.x.

MANGINO, M.E. Physicochemical aspects of whey protein functionality. Journal of Dairy Science, v.67, n.11, p.27112722, 1984. Available from: <http://www.sciencedirect.com/ science/article/pii/S002203028481629X>. Accessed: Nov. 19, 2010. doi: 10.3168/jds.S0022-0302(84)81629-X.

MARTÍN-DIANA, A.B. et al. Development of a fermented goat's milk containing probiotic bacteria. International Dairy Journal, v.13, n.10, p.827-833, 2003. Available from: <http:/ / w w w. sciencedirect.com/s cience/article / p i i / S0958694603001171>. Accessed: Dez. 5, 2010. doi: 10.1016/ S0958-6946(03)00117-1

MORETI, B.R. Efeito da suplementação do leite com proteínas de diferentes fontes (soro de leite, soja e colágeno) e da composição da cultura lática em iogurtes. 2009. 160f. Dissertação (Mestrado em Engenharia e Ciência de Alimentos) - Curso de Pós-graduação em Engenharia e Ciência de Alimentos, Universidade Estadual Paulista “Júlio de Mesquita Filho, SP.

OLIVEIRA, M.E.G. Desenvolvimento de formulações de bebidas lácteas fermentadas a partir de soro e leite de cabra. 2009. 77f. Dissertação (Mestrado em Ciências e Tecnologia de Alimentos) - Curso de Pós-graduação em Ciência e Tecnologia de Alimentos, Universidade Federal da Paraíba, PB.

PELEGRINE, D.H.et al. Estudo da vicosidade aparente das polpas de manga (Keitt) e abacaxi (Pérola). Ciência e Tecnologia de Alimentos, v.20, p.128-131, 2000. Available from:: <http:// www.scielo.br/scielo.php? script $=$ sci_arttext $\&$ pid $=$ S 0 10120612000000100024\&lng=en\&nrm=iso > . Accessed: Jan. 10, 2011. doi: 10.1590/S0101-20612000000100024.

R DEVELOPMENT CORE TEAM. R: a language and environment for statistical computing. Vienna: $R$ Foundation for Statistical Computing, 2009. Available from: <http://www.r-project.org>. Accessed: Dez. 10, 2010.

RICHARDS, N.S.P.S. et al. Avaliação físico-química da qualidade do leite de cabra pasteurizado comercializado na Grande Porto Alegre, RS. Revista do Instituto de Laticínios Cândido Tostes, v.56, n.321, p.212-216, 2001.

RIENER, J. et al. A comparison of selected quality characteristics of yoghurts prepared from thermosonicated and conventionally heated milks. Food Chemistry, v.119, p.1108-1113, 2010. Available from: <http://www.sciencedirect.com/science/article/ pii/S0308814609009984>. Accessed: Fev. 2, 2011. doi: 10.1016/j.foodchem.2009.08.025.

RICCIARDI, A.; CLEMENTI, F. Exopolysaccharide from lactic acid bactéria: Struture, production and technological applications. Italian Journal of Food Science, v.12, n.1, p.23-45, 2000.

SAXELIN, M. et al. The technology of probiotics. Trends in Food Science and Technology, v.10, p.387-392, 1999.

SHENE, C.; BRAVO, S. Whey fermentation by Lactobacillus delbrueckii subsp. Bulgaricus for exopolysaccharide production in continuous culture. Enzyme and Microbiol Technology, v.38, n.2, p.1-7, 2006. Available from: <http:// w w w. sciencedirect.com/s c i ence/article/pi i / S0141022906005631>. Accessed: Dez. 1, 2010. doi: 10.1016/ j.enzmictec.2006.11.003.

TAMINE, A.Y; DEETH, H.C. Yogurt: tecnhnology and biochemistry. Journal Food Protection, v.43, n.12, p.939977, 1980.

TAMINE, A.Y; DEETH, H.C. Yogurt: ciencia y tecnhnology. Zaragoza: Acribia, 1991. 368p. 